\title{
KEGIATAN FARMAKOLOGIS DARI BERBAGAI BAGIAN Carica papaya Linn. EKSTRAK: BUAH, DAUN, BENIH, UAP, KULIT DAN AKAR
}

\author{
Tita Khosima Hidayati ${ }^{1}$, Yasmiwar Susilawati ${ }^{2}$, Ahmad Muhtadi $^{3}$ \\ ${ }^{1,3}$ Departemen Farmakologi dan Klinik Farmasi, Fakultas Farmasi, Universitas \\ Padjajaran \\ ${ }^{2}$ Departement Biologi Farmasi, Fakultas Farmasi, Universitas Padjajaran \\ Email korespondensi: tita17003@mail.unpad.ac.id
}

\begin{abstract}
ABSTRAK
Carica papaya (Caricaceae) Linn. (CP) adalah tanaman tropis populer yang memberikan manfaat besar. Buahnya enak dan sehat sementara bagian lain memiliki potensi sifat obat yang besar. CP diklasifikasikan sebagai tanaman yang memiliki aktivitas anti-mikroba, anti oksidan, anti malaria, anti maag, anti-HIV, antiinflamasi, anti kanker, anti hipertensi, anti kesuburan, anti jamur dan anti diabetes. Aktivitas farmakologis tanaman pepaya terkait dengan kandungan senyawa fitokimia alkaloid, flavonoid, tannin, saponin, enzim: papain dan chymopapain. Kandungan fitokimia ini telah ditemukan pada daun muda, kulit batang, biji kering. Daun pepaya mengungkapkan lebih banyak aktivitas farmakologis karena memiliki beragam kandungan fitokimia. Dalam ulasan ini akan dipelajari kegiatan farmakologis dari Carica papaya Linn. ekstrak yang diperoleh dari buah, daun, biji, kulit batang dan akar. Selain itu, berbagai kandungan fitokimia mereka juga dijelaskan.
\end{abstract}

Kata kunci : Carica papaya Linn., Konstituen fitokimia , Aktivitas farmakologi 


\title{
PHARMACOLOGICAL ACTIVITIES OF VARIOUS PARTS Carica papaya Linn. EXTRACT: FRUIT, LEAF, SEED, STEAM, BARK AND ROOT
}

\begin{abstract}
Carica papaya (Caricaceae) Linn. (CP) is a popular tropical plant which provide a huge benefit. The fruit is either delicious and healthy while other parts have a great potential medicinal properties. CP are classified as plants that have antimicrobial activity, anti oxidant, anti malaria, anti-ulcer, anti-HIV, anti-inflammatory, anti-cancer, anti-hypertension, anti-fertility, anti-fungal and anti diabetic. Pharmacological activity of papaya plants related to the content of phytochemical compounds of alkaloid, flavonoid, tannin, saponin, enzyme: papain and chymopapain. These phytochemical content have been found in the young leaf, stem bark, dry seeds. Papaya leaf reveal more pharmacologycal activities because that have wide variety of phytochemical contents. In this review will be studied pharmacologycal activities of Carica papaya Linn. extract that obtained from fruit, leaf, seeds, stem bark and root. Besides, their various phytochemical contents are also described.
\end{abstract}

Keywords : Carica papaya Linn., Phytochemical contents, Pharmacological activities

\section{PENDAHULUAN}

Carica papaya (Caricaceae) Linn. (CP) adalah pohon umbuh di daerah tropis, yang merupakan tanaman asli Amerika Selatan. Tanaman ini tidak bercabang, pohon kecil, batang tunggal yang tumbuh setinggi 5-10 m. Daunnya besar, berdiameter $50-70 \mathrm{~cm}$, dengan 7 lobus, sangat melengkung (Maniyar and Bhixavatimath, 2012). Buah Carica papaya Linn. (CP) adalah buah yang dapat dikonsumsi baik sebagai buah segar maupun olahan. Buahnya merupakan sumber betakarotene yang bersifat antioksidan karena dapat mencegah kerusakan yang disebabkan oleh radikal bebas. Buah papaya mengandung vitamin $\mathrm{C}$, vitamin $\mathrm{A}$, vitamin $\mathrm{E}$, mineral, magnesium, kalium, vitamin B, asam pantoneat, folat dan serat. Selain itu, juga mengandung enzim papain yang dapat membantu pencernaan protein (Tarun, 2015). Bagian lain dari CP juga bermanfaat seperti daun dan getah Carica papaya Linn. yang diketahui digunakan untuk mengobati demam tifoid, infeksi luka, asma, diare, hipertensi dan sebagainya (Maniyar and Bhixavatimath, 2012). Ekstrak buah dan biji memiliki aktivitas antibakteri melawan Staphylococcus aureus, Bacillus cereus, Escherischia coli, dan Pseudomonas (Emeruwa, 1982). Telah dilaporkan CP mempunyai aktivitas farmakologis lainnya seperti antifertilitas, anti-inflamasi, anti-tumor, antimalaria, dan anti diabetes. 


\section{METODE PENELITIAN}

\section{Buah}

Buah pepaya (Gambar 1 )memiliki bentuk besar, berair, dan mirip melon yang memiliki biji hitam di bagian tengah (Karunamoorthi, H.-M. Kim, et al., 2014); dan merupakan sumber provitamin A, asam amino karotenoid, vitamin $\mathrm{C}$, vitamin $\mathrm{B}$, mineral, lycopene dan serat makanan (Karunamoorthi, H.M. Kim, et al., 2014).

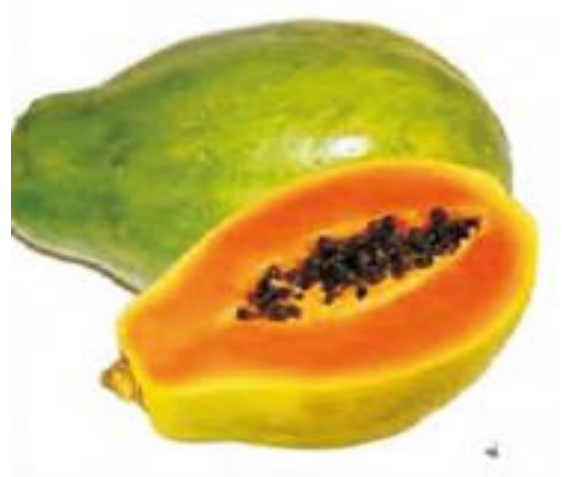

Gambar 1. Buah papaya (Tarun, 2015)

Tingkat kematangan buah papaya digambarkan dengan skor kematangan $0-5$. Skor 0 menunjukan buah mentah berwarna hijau $100 \%$, skor 1 warna buah dengan area kuning 0- $25 \%$ dari kulit, skor $21 / 4$ matang, buah hingga $25 \%$ dari permukaan kuning dikelilingi oleh warna hijau muda, skor $31 \frac{1}{2}$ matang, buah hingga $50 \%$ dari permukaan kuning dikelilingi oleh warna hijau muda, skor $43 / 4$ matang, buah hingga $50-75 \%$ dari permukaan kuning dikelilingi oleh warna hijau muda, Dewasa, buah hingga 75 - 100\% permukaan kuning, hanya area di dekat batang berwarna hijau (Basulto et al., 2009).

Kandungan kimia yang terdapat dalam buah pepaya adalah protein, lemak, serat, karbohidrat, mineral (kalsium dan zat besi), vitamin $\mathrm{C}$, tiamin, riboflavin, niasin, karoten, asam amino, asam sitrat dan asam malat (buah hijau), senyawa mudah menguap: benzylisothiocynate, cis dan trans 2,6-dimethyl-3,6 epoxy-7 octen-2-ol, dan alkaloid carpaine (Tarun, 2015). Sedangkan jus nya mengandung asam butirat, asam heksanoat, asam okatanoat lipid; asam miristat, asam palmitat, asam stearat, asam linolenat, asam linoleat, dan asam oleat (Tarun, 2015) Komposisi kimiawi buah pepaya dipengaruhi oleh tahap kematangan. Tabel 1 menyajikan perbandingan fitonutrien pepaya matang dan mentah. 
Tabel 1. Kandungan Fitonutrisi 100 g Buah Pepaya Matang dan Muda (Karunamoorthi, H. M. Kim, et al., 2014)

\begin{tabular}{llcc}
\hline No & Fitonutrisi & \multicolumn{2}{c}{ Buah Pepaya } \\
\cline { 3 - 4 } & & Mentah & Matang \\
\hline 1 & Kalori & $26 \mathrm{cal}$ & $46 \mathrm{cal}$ \\
2 & Vitamin A & $50 \mathrm{SI}$ & $365 \mathrm{SI}$ \\
3 & Vitamin B1 & $0.02 \mathrm{mg}$ & $0.04 \mathrm{mg}$ \\
4 & Vitamin C & $19 \mathrm{mg}$ & $78 \mathrm{mg}$ \\
5 & Kalsium & $50 \mathrm{mg}$ & $23 \mathrm{mg}$ \\
6 & Karbohidrat & $4.9 \mathrm{~g}$ & $12.2 \mathrm{~g}$ \\
7 & Fosfor & $16 \mathrm{mg}$ & $12 \mathrm{mg}$ \\
8 & Iron & $0.4 \mathrm{mg}$ & $1.7 \mathrm{mg}$ \\
9 & Protein & $2.1 \mathrm{~g}$ & $0.5 \mathrm{mg}$ \\
10 & Air & $92.4 \mathrm{~g}$ & $86.7 \mathrm{~g}$ \\
\hline
\end{tabular}

Kandungan papain dalam pepaya mentah lebih tinggi dari pada yang sudah matang. Papain adalah enzim penting yang bermanfaat untuk membantu pencernaan. Karena itu buah pepaya banyak digunakan untuk menyembuhkan gangguan pencernaan. Papain juga digunakan dalam pelunak daging, obat-obatan, produk kecantikan, dan kosmetik (Karunamoorthi, H. M. Kim, et al., 2014).

\section{Daun}

Pepaya memiliki daun yang tersusun secara spiral di bagian atas dilengkapi tangkai daun sekitar $1 \mathrm{~m}$, daunnya memiliki warna kehijauan atau keunguan (Karunamoorthi, H.-M. Kim, et al., 2014) Tingklat kedewasaan daun dapat diklasifikasikan seperti disajikan pada Gambar 1.
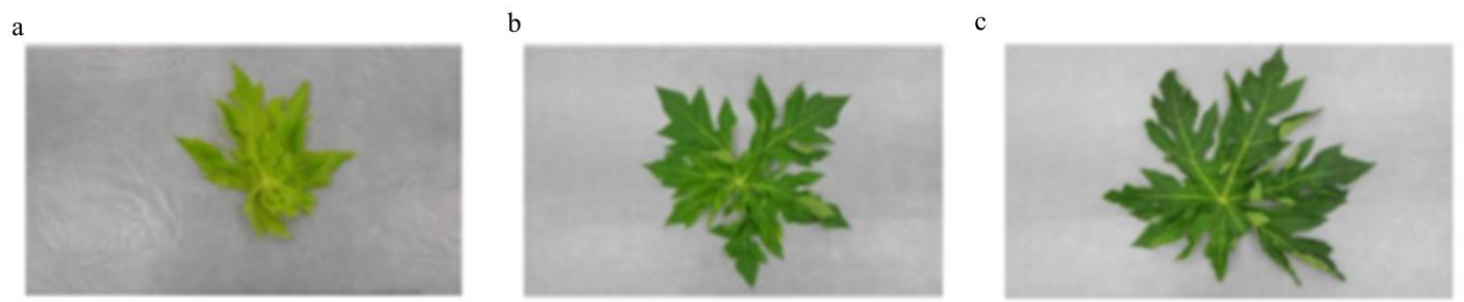
Gambar 1. Tingkat kedewasaan daun pepaya: a. tahap 1, pucuk/daun muda yang baru mengembang dengan warna hijau muda, b. tahap 2, daun muda dan sebagian dewasa dengan warna hijau, c. tahap 3, daun dewasa penuh dengan warna hijau gelap.

Senyawa alkaloid, carpain, enzim (papain, chymopapain, cystatin), tokoferol, Asam amino, flavonoid, tanin, asam nikotinat, saponin, dan senyawa lainnya telah dilaporkan terdapat pada bagian daun papaya (Achudhan, 2008). Canini, et.al 2007, telah mengungkapkan adanya asam fenolik(asam kafeat, asam p-kumarat, asam protokatekuat) sebagai fitokimia utama. Kuersetin dan kaempferol adalah senyawa utama yang ditemukan pada daun papaya muda dengan jumlah flavonoid paling tinggi (Omar et al., 2016). Vitamin yang terkandung dalam daun pepaya antara lain niasin, tiamin dan riboflavin (Nwofia, Ojimelukwe and Eji, 2012)

\section{Biji}

Biji pepaya berwarna hitam, rasa tajam, pedas (Aravind et al., 2013). Biji

pepaya kering mirip dengan merica dan dapat digunakan dengan cara yang sama ditambahkan pada makanan terutama makanan kaya protein (Yogiraj et al., 2014). Gosh, et.al mengungkapkan buah dan biji dapat dimakan langsung, biji pepaya tinggi akan enzim proteolitik yaitu papain. Biji mengandung asam lemak, protein kasar, serat kasar, minyak pepaya, carpaine, caricin, glucotropacolin, dan enzim myrosin (Tarun, 2015)

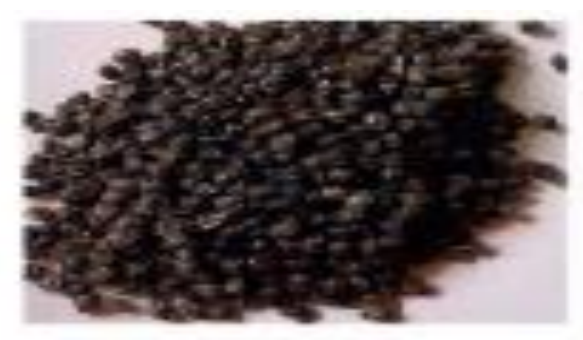

Gambar 2. Biji papaya (Goku et al., 2020)

\section{Batang}

Selama pertumbuhan awal pohon papaya tidak bercabang, tinggi pohon mencapai 3 hingga $10 \mathrm{~m}$. Setelah mencapai kematangan pada pohon, tunas baru muncul di bagian bawah batang dan berkembang menjadi cabang setelah mencapai tinggi maksimum. Batang papaya tebal, terdiri satu lapis floem sekunder, kaya serat, dan dua lapisan skelerenkim yang terletak tepat di dalam kulit kayu (Yogiraj et al., 2014). Kandungan kimia yang terkandung di batang yaitu $\beta$-sitosterol, glukosa, fruktosa, sukrosa, galaktosa dan xylitol (Tarun, 2015)

Hampir semua bagian tumbuhan papaya memiliki aktivitas farmakologi hal ini di ikhtisarkan pada Tabel 1 di bawah ini 
Tabel 1. Aktivitas Farmakologi Ekstrak dari Berbagai Bagian Tumbuhan Carica papaya( Linn.)

\begin{tabular}{|c|c|c|c|c|}
\hline $\begin{array}{c}\text { Aktivitas } \\
\text { Farmakologi } \\
\text { s }\end{array}$ & 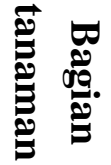 & 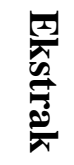 & $\begin{array}{c}\text { Model } \\
\text { pengujian }\end{array}$ & Hasil \\
\hline
\end{tabular}

\begin{tabular}{|c|c|c|c|c|c|}
\hline \multirow[t]{7}{*}{$\begin{array}{l}\text { Anti } \\
\text { Diabetes }\end{array}$} & Daun & Air & STZ, ip & $\begin{array}{l}\text { Signifikan } \\
\text { menurunkan kadar } \\
\text { glukosa darah pada } \\
\text { tikus diabetes, dan } \\
\text { penurunan kolesterol. }\end{array}$ & $\begin{array}{l}\text { (Juárez- } \\
\text { Rojop et al., } \\
\text { 2012) }\end{array}$ \\
\hline & Daun & $\begin{array}{l}\text { Etan } \\
\text { ol }\end{array}$ & $\begin{array}{l}\text { Alloxan } \\
\text { monohidrat }\end{array}$ & $\begin{array}{l}\text { Signifikan menunda } \\
\text { aktivitas hipoglikemia } \\
\text { glimepiride, dan } \\
\text { meningkatkan efek } \\
\text { hipoglikemik } \\
\text { Metformin }\end{array}$ & $\begin{array}{l}\text { (Fakeye et } \\
\text { al., 2007) }\end{array}$ \\
\hline & Daun & $\begin{array}{l}\text { klor } \\
\text { ofor } \\
\mathrm{m}\end{array}$ & STZ & $\begin{array}{l}\text { Penurunan glukosa } \\
\text { serum, trigliserida dan } \\
\text { transaminase }\end{array}$ & $\begin{array}{l}\text { (Juárez- } \\
\text { Rojop et al., } \\
\text { 2014) }\end{array}$ \\
\hline & Daun & Air & Alloxan & $\begin{array}{l}\text { Signifikan } \\
\text { menurunkan dalam } \\
\text { kadar glukosa darah } \\
\text { dan tingkat profil lipid } \\
\text { serum. }\end{array}$ & $\begin{array}{l}\text { (Maniyar } \\
\text { and } \\
\text { Bhixavatim } \\
\text { ath, 2012) }\end{array}$ \\
\hline & Biji & Air & $\begin{array}{l}\text { Tanap } \\
\text { induksi }\end{array}$ & $\begin{array}{l}\text { Signifikan } \\
\text { menurunkan glukosa } \\
\text { darah puasa, } \\
\text { Trigliserida, kolesterol } \\
\text { total dan VLDL }\end{array}$ & $\begin{array}{l}\text { (Adeneye } \\
\text { and } \\
\text { Olagunju, } \\
\text { 2009) }\end{array}$ \\
\hline & $\begin{array}{l}\text { Kulit } \\
\text { batan } \\
\text { g }\end{array}$ & Air & Alloxan & $\begin{array}{lr}\text { Pengurangan } & \text { glukosa } \\
\text { darah } & \text { secara } \\
\text { signifikan } & \end{array}$ & $\begin{array}{l}\text { (Saidu, A.N } \\
\text { and Nweri } \\
\text { c, 2013) }\end{array}$ \\
\hline & Buah & Air & $\begin{array}{l}\text { In vitro } \\
\text { dengan }\end{array}$ & $\begin{array}{l}\text { Aktifitas } \\
\text { penghambatan }\end{array}$ & $\begin{array}{l}\text { (Oboh et } \\
\text { al., 2014) }\end{array}$ \\
\hline
\end{tabular}




$\begin{array}{llr}\text { pengujian } & \text { kuat dari buah pepaya } \\ \alpha \text {-amilase, } & \text { mentah terhadap } \\ \alpha \text { - } & \text { enzim yang terkait } \\ \text { glukosidase } & \text { dengan diabetes tipe 2 } \\ \text { dan } & \alpha \text {-amilase, } & \alpha- \\ \text { peroksidasi } & \text { glukosidase dan } \\ \text { lipid yang } & \text { peroksidasi lipid } \\ \text { diinduksi } & \\ \text { Sodium } & \\ \text { nitroprussid } & \\ \text { e pada } & \\ \text { pankreas } & \end{array}$

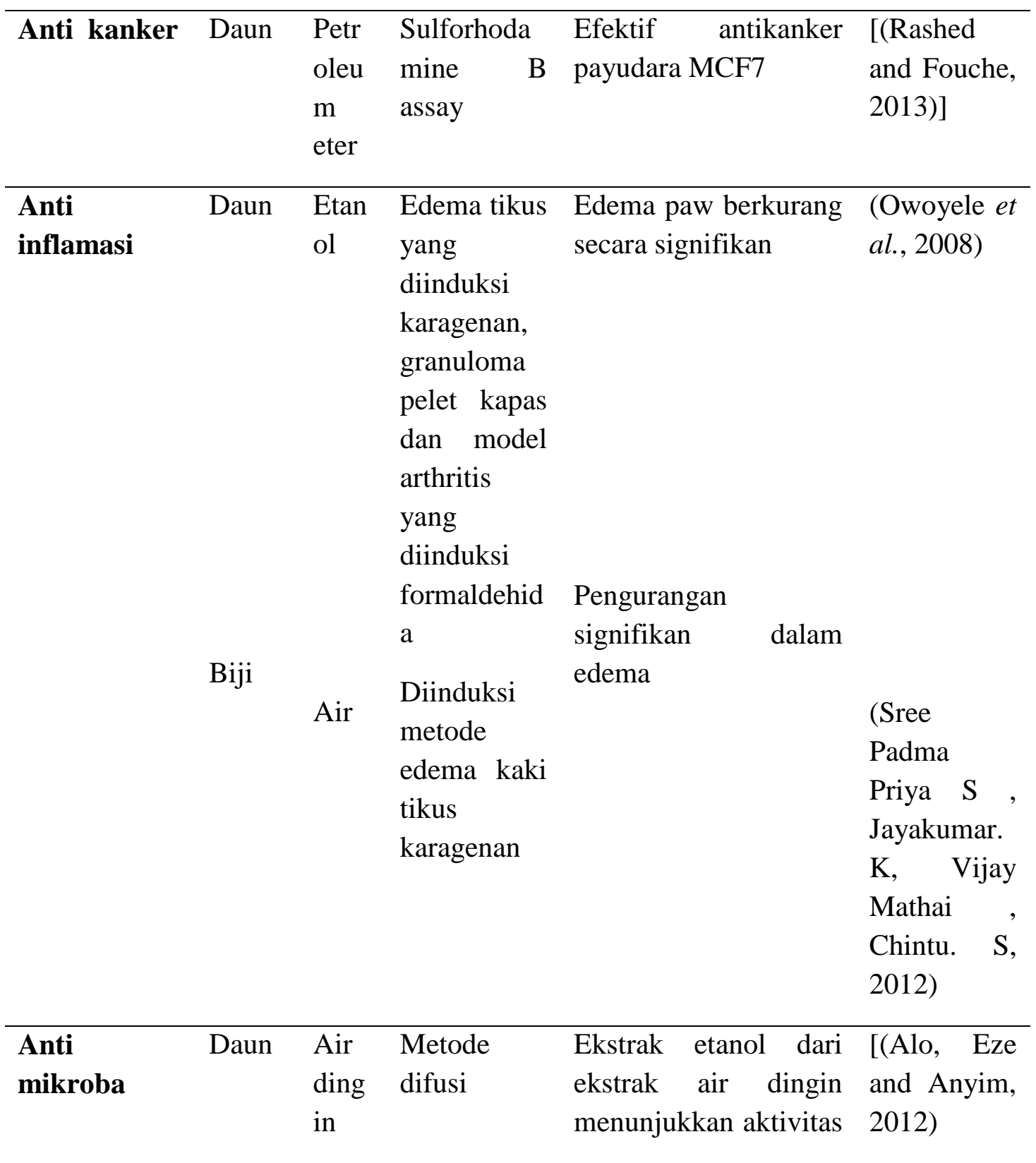




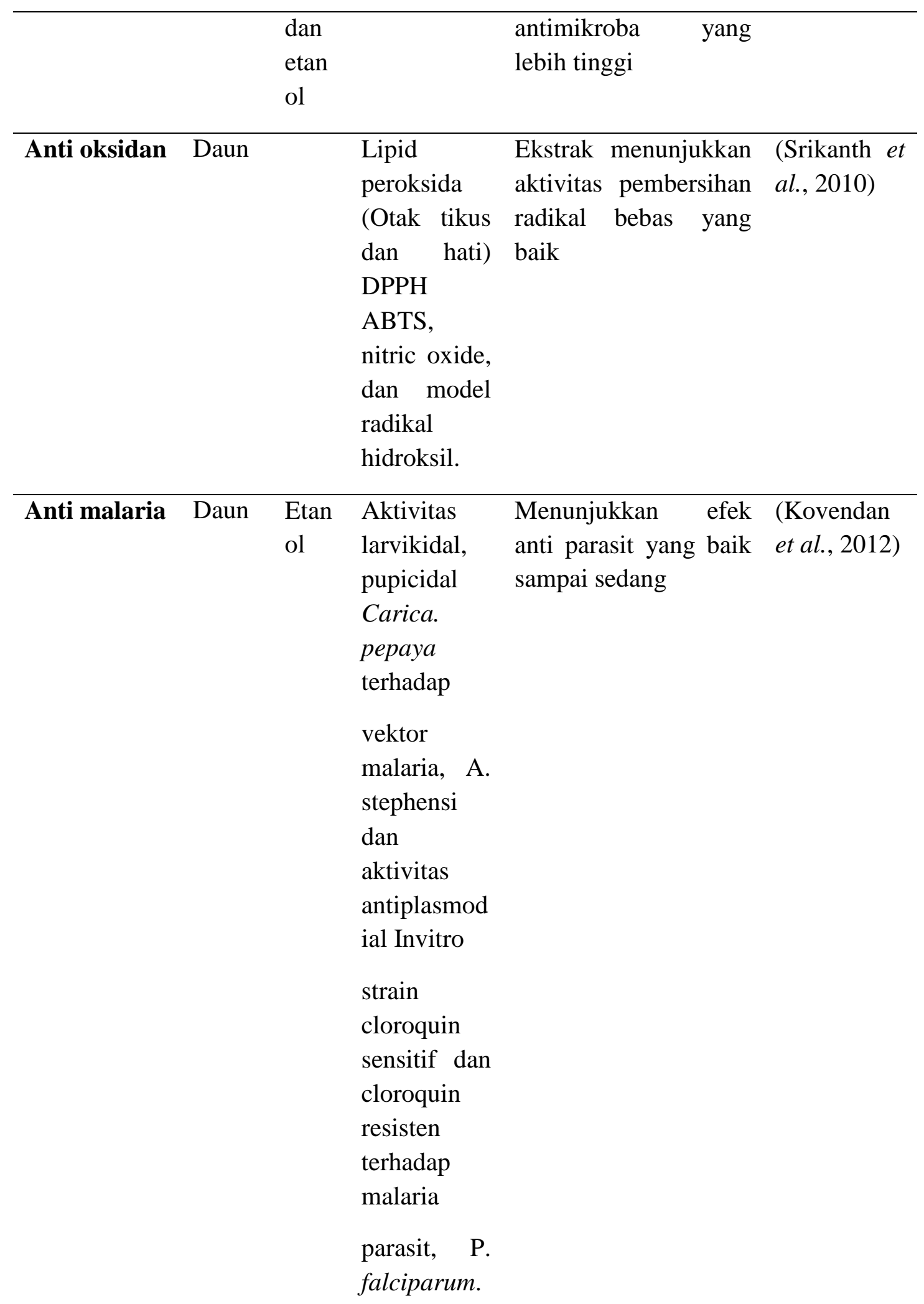

\begin{tabular}{lllllrl}
\hline Anti fungi & Daun & $\begin{array}{l}\text { Etan } \\
\text { ol }\end{array}$ & $\begin{array}{l}\text { Metode } \\
\text { agar }\end{array}$ & $\begin{array}{l}\text { Ekstrak } \\
\text { menunjukkan }\end{array}$ & $\begin{array}{r}\text { dingin } \\
\text { zona }\end{array}$ & 2012) \\
& & & & &
\end{tabular}




\begin{tabular}{|c|c|c|c|c|c|}
\hline & & $\begin{array}{l}\text { ding } \\
\text { in } \\
\text { dan } \\
\text { pana } \\
\mathrm{s}\end{array}$ & & $\begin{array}{l}\text { penghambatan } \\
\text { pertumbuhan yang } \\
\text { lebih tinggi terhadap } \\
\text { Rhizopus nigricans } \\
\text { dan mucor } \\
\text { circinelloides daripada } \\
\text { efek ekstrak panas } \\
\text { hanya anti jamur } \\
\text { Rhizopus nigricant }\end{array}$ & \\
\hline Anti ulkus & $\begin{array}{l}\text { Buah } \\
\text { menta } \\
\text { h }\end{array}$ & $\begin{array}{l}\text { Etan } \\
\text { ol } \\
\text { /HC } \\
\mathrm{L} \\
\text { dan } \\
\text { Indo } \\
\text { meta } \\
\text { cin }\end{array}$ & $\begin{array}{l}\text { Induksi } \\
\text { etanol / } \\
\text { HCL dan } \\
\text { induksi } \\
\text { indometacin } \\
\text { sehingga } \\
\text { terjadi } \\
\text { ulcus, } \\
\text { sekresi } \\
\text { asam dan } \\
\text { lendir } \\
\text { diukur pada } \\
\text { hewan yang } \\
\text { mengalami } \\
\text { ulserasi dan } \\
\text { yang diobati }\end{array}$ & 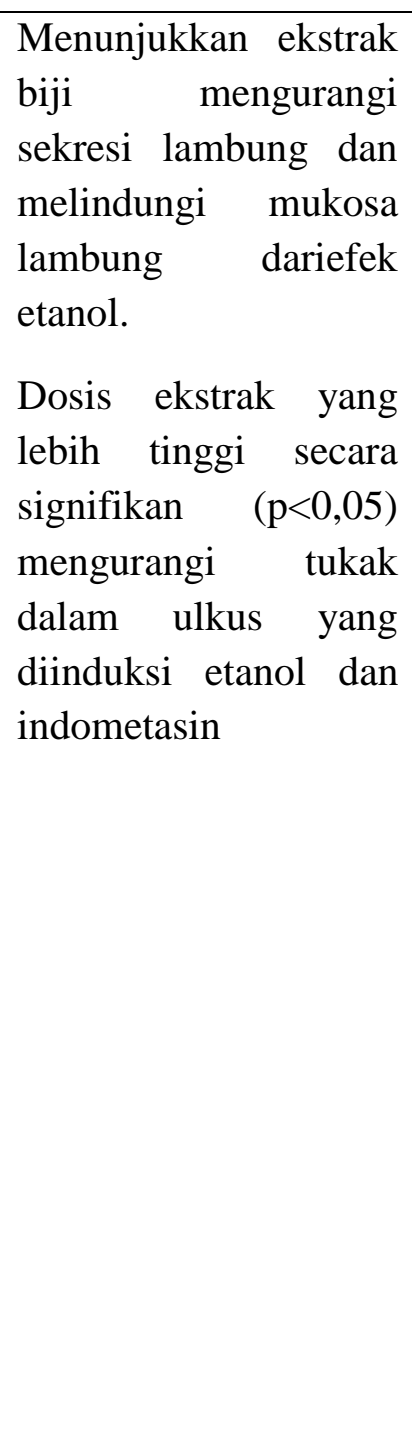 & $\begin{array}{l}\text { (Tolunigba } \\
\text { Abisola and } \\
\text { Adekunle } \\
\text { Wahab, } \\
\text { 2012) }\end{array}$ \\
\hline
\end{tabular}

Anti HIV

Daun

$\begin{array}{ll}\text { Met } & \text { Uji formas } \\ \text { anol } & \text { Syncytia } \\ \text { dan } & \\ \text { air } & \end{array}$

Menunjukkan

(Rashed et aktivitas anti HIV, al., 2013) indeks terapi ekstrak sebesar 5,51 dan 7,13 
dibandingkan dengan

obat standar

\begin{tabular}{|c|c|c|c|c|c|}
\hline $\begin{array}{l}\text { Anti- } \\
\text { fertilitas }\end{array}$ & Biji & $\begin{array}{l}\text { Etan } \\
\text { ol }\end{array}$ & $\begin{array}{l}\text { Profil } \\
\text { semen, } \\
\text { kesuburan, } \\
\text { berat organ } \\
\text { dan } \\
\text { toksisitas }\end{array}$ & $\begin{array}{l}\text { Analisis histologis } \\
\text { menunjukkan keadaan } \\
\text { normal pada hari ke } \\
30,40 \text { tidak ada } \\
\text { perubahan pada berat } \\
\text { organ, tidak } \\
\text { toksikologi respon } \\
\text { menunjukan pada hal } \\
\text { yang tidak diinginkan }\end{array}$ & $\begin{array}{l}\text { (Lohiya } \\
\text { al., 1994) }\end{array}$ \\
\hline
\end{tabular}

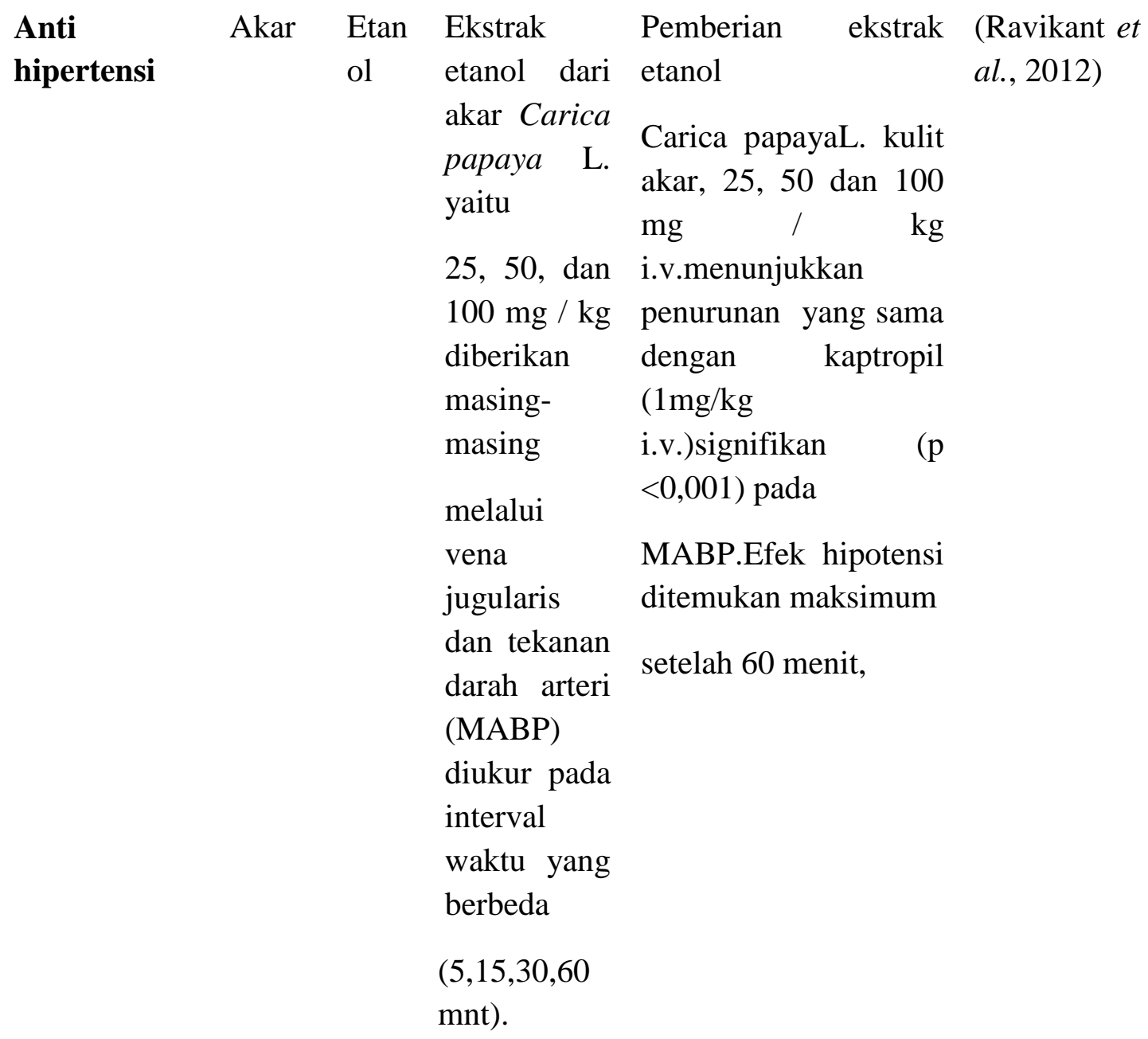

Setiap bagian carica papaya telah menunjukan potensi berbagai aktivitas farmakologi. Hal ini dapat disebabkan oleh adanya kandungan senyawa fitokimia didalam Carica papaya Linn. Berbagai kandungan fitokimia dicantumkan pada Tabel 4. 
Table 4. Konstituen Fitokimia dari Carica Papaya Linn

\begin{tabular}{|c|c|c|}
\hline Bagian tanaman & Konstituen & Reference \\
\hline Buah & $\begin{array}{l}\text { Protein, lemak, serat, karbohidrat, } \\
\text { Kalsium, zat besi, vitamin C, tiamin, } \\
\text { riboflavin, niasin, dan karoten, asam } \\
\text { amino, asam sitrat dan asam malat } \\
\text { (buah hijau), senyawa volatil: } \\
\text { benzylisothiocynate, cis dan trans 2, } \\
\text { 6-dimethyl-3,6 epoxy-7 oktan -2-ol, } \\
\text { alkaloid, carpaine, benzyl tanin, } \\
\text { glikosida jantung. }\end{array}$ & $\begin{array}{l}\text { (Tarun, 2015) } \\
\text { (Krishna, Paridhavi } \\
\text { and Patel, 2008) }\end{array}$ \\
\hline Daun & $\begin{array}{l}\text { Alkaloid carpain, } p \text { dehydrocarpaine I } \\
\text { dan II, Flavonoid, choline, vitamin C } \\
\text { dan E, carposide, tannin, glikosida } \\
\text { jantung, antraquinon, gula reduksi, } \\
\text { steroid, saponin. }\end{array}$ & $\begin{array}{l}\text { (Tarun, 2015) } \\
\text { (Krishna, Paridhavi } \\
\text { and Patel, 2008) } \\
\text { (Ayoola, Adeyeye } \\
\text { and State, 2010) }\end{array}$ \\
\hline Biji & $\begin{array}{l}\text { Asam lemak, protein kasar, serat } \\
\text { kasar, minyak pepaya, carpaine, } \\
\text { caricin, glucotropacolin, enzim } \\
\text { myrosin. alkaloid, tanin, fenol, } \\
\text { antrakuinon, glikosid jantung }\end{array}$ & $\begin{array}{l}\text { (Tarun, 2015) } \\
\text { (Eke, Augustine and } \\
\text { Ibrahim, 2014) }\end{array}$ \\
\hline Kulit batang pohon & $\begin{array}{l}\text { Alkaloid, tannin, saponin, glikosida } \\
\text { jantung, fenol, steroid }\end{array}$ & $\begin{array}{l}\text { (Saidu, A.N and } \\
\text { Nweri c, 2013) }\end{array}$ \\
\hline Akar & $\begin{array}{l}\text { Carposide dan enzym myrosin, fenol, } \\
\text { glikosida jantung, saponin , tanin, } \\
\text { alkaloids }\end{array}$ & $\begin{array}{l}\text { (Tarun, 2015) } \\
\text { (Hamuel, 2007) } \\
\text { (Krishna, Paridhavi } \\
\text { and Patel, 2008) }\end{array}$ \\
\hline
\end{tabular}

HASIL DAN PEMBAHASAN

Di antara bagian Carica papaya Linn., ekstrak bagian daun adalah ekstrak yang paling banyak menunjukkan aktivitas farmakologis. Aktivitas ini diduga dari senyawa yang terkandung di dalamya, seperti tercantum dalam Tabel 4.

Menurut Miean dan Mohamed (2001) daun papaya mempunyai kadar flavonoid yang tinggi dan senyawa utama dari flavonoid ini adalah quercetin dan kaemferol. Quercetin 
merupakan flavonoid bentuk flavonol yang memiliki aktivitas farmakologi antioksidan yang kuat. Aktivitas flavonol timbul karena adanya gugus aromatik cincin B yang mempunyai ikatan rangkap konjugasi pada nomor $2^{\prime}$ dan $3^{\prime}$ sehingga memiliki kemampuan untuk perpindahan elektron dari cincin B kepada radikal bebas dan memecah radikal bebas. Berdasarkan studi in silico oleh Madeswaran et al. (2011) golongan flavonol potensial sebagai anti-inflamasi, hal ini dibuktikan dengan energi ikatan flavonoid pada situs siklooksigenase yaitu $\quad-8.77$ $\mathrm{kcal} / \mathrm{mol}$ hingga $6.24 \mathrm{kcal} / \mathrm{mol}$ yang tidak berbeda jauh jika dibanding standar Celecoxib (-8.30 kcal $/ \mathrm{mol})$. Menurut Sangeetha et al. (2016) flavonoid sebagai anti inflamasi bekerja dengan cara memproduksi pro inflamatori mediator menstimulasi sel yang berkaitan dengan inflamasi seperti limfosit, monosit, natural killer sel, neutrophil, makrofag, dan sel mastosit.

Senyawa quersetin yang merupakan derivat flavonoid memberikan aktivitas sebagai anti mikroba. Penelitian yang dilakukan Wang et al. (1992) menunjukan pembentukan komplek 5-hidroksi-7,4'dimetoksiflavon dengan logam meningkatkan aktivitas antibakteri. Aktivitas ini diakibatkan oleh 3,4hidroksi pada cincin C. Dengan adanya gugus hiroksi tersebut flavonoid akan membentuk kompleks dengan protein pada bakteri dan menyebabkan membran bakteri tersebut (Cushnie and Lamb, 2005).
Flavonoid dilaporkan memiliki aktivitas antidiabetes yang bekerja pada target biologis yang terlibat dalam diabetes melitus. Flavonoid bekerja sebagai penghambat enzim $\alpha$ glucosidase, dimana flavonoid terlibat dalam memecah kompleks karbohidrat, dalam hal membantu penyerapan karbohidrat, sehingga terjadi peningkatan postprandial glikemik dan insulin. Pada PPAR-g, flavonoid mengatur penyimpanan asam lemak dan metabolisme glukosa. Flavonoid mengurangi efek hiperglikemi karena aktivitas antioksidannya. Maheswari, et al.2017 mengungkapkan quercetin pada diabetes mellitus 1 meningkatkan pelepasan insulin dengan regenerasi sel prankreas (Nicolle et al., 2011)

Komplikasi diabetes seperti neuropati, retinopati dan nefropati disebabkan oleh peningkatan fluks jalul poliol, aktivasi isomer protein kinase $\mathrm{C}$, pembentukan produk akhir glikasi lanjut (AGEs), dan peningkatan dalam fluks jalur hexosamine. Pada aldose reductase flavonoid terlibat dalam jalur poliol, glukosa pecah menjadi sorbitol dan akumulasinya terkait dengan komplikasi diabetes dan terlibat dalam pembentukan lanjutan produk glikasi.

Flavonoid quercetin yang terdapat dalam daun mempunyai aktivitas farmakologi sebagai anti kanker dengan mekanisme antiproliferasi, inhibisi angiogenesis, dan inhibisi CYP3A4 (Maheswari et al., 2016). Sebaliknya kulit batang pohon memiliki aktivitas farmakologis yang lebih sedikit hal ini mungkin berhubungan dengan konstituen kimia 
yang dimilikinya. Hasil ini menyiratkan korelasi antara konstituen kimia yang terkandung dalam Carica papaya Linn. ekstrak dengan aktivitas farmakologinya.

\section{SIMPULAN}

Berdasarkan hasil literature rivieuw ekstrak buah, daun, biji, kulit kayu, dan akar Carica papaya Linn. memiliki berbagai aktivitas farmakologis yang dibuktikan secara in vitro dan in vivo Ekstrak daun Carica papaya Linn. menunjukkan aktivitas farmakologis yang lebih banyak dan signifikan seperti anti diabetes, anti kanker, anti inflamasi, anti mikroba, anti oksidan, anti malaria, dan anti HIV. Konstituen kimia yang diketahu sebagai komponen aktif dari daun papaya adalah flavonoid quercetin dan kaempferol. Kedepannya diharapkan dengan diketahui informasi fitokimia dan aktivitas farmakologis dari bagian tanaman Carica papaya Linn. dapat dikembangkan menjadi suatu produk obat dengan aktivitas yang beragam.

\section{UCAPAN TERIMAKASIH}

Ucapan terima kasih kepada Dr. Aliya $\mathrm{NH}$ yang telah membantu dalam keberhasilan penelitian ini.

\section{DAFTAR PUSTAKA}

Achudhan, V. V (2008) 'Antimicrobial and Phytochemical Investigation of the Leaves of Carica papaya L., Cynodon dactylon (L.) Pers., Euphorbia hirta L', Ethnobotanical Leaflets, 12, pp. 1184-
91.

Adeneye, A. A. and Olagunju, J. A. (2009) 'Preliminary hypoglycemic and hypolipidemic activities of the aqueous seed extract of Carica papaya Linn. In wistar rats', Biology and Medicine, 1(1), pp. 1-10.

Alo, M., Eze, U. A. and Anyim, C. (2012) 'Invitro Antimicrobial Activities of Extracts of Magnifera indica, Carica papaya and Psidium guajava Leaves on Salmonella typhi Isolates', World J Public Health Sciences World Journal of Public Health Sciences, 11(11), pp. $1-6$.

Aravind, G. et al. (2013) 'Traditional and Medicinal Uses of Carica papaya', Journal of Medicinal Plants Studies, 1(1), pp. 7-15.

Ayoola, P. B., Adeyeye, A. and State, O. (2010) 'Phytochemical and Nutrient Evaluation of Carica Papaya ( Pawpaw ) Leaves .', 5(December), pp. 325-328.

Basulto, F. S. et al. (2009) 'Postharvest ripening and maturity indices for maradol papaya', Interciencia, 34(8), pp. 583-588.

Cushnie, T. P. T. and Lamb, A. J. (2005) 'Antimicrobial activity of flavonoids', International Journal of Antimicrobial Agents, 26(5), pp. 343356. doi: 10.1016/j.ijantimicag.2005.09.002.

Eke, O. N., Augustine, A. U. and Ibrahim, H. F. (2014) 'Qualitative Analysis of Phytochemicals and Antibacterial Screening of Extracts of Carica papaya Fruits and Seeds', 
International Journal of Modern Chemistry, 6(1), pp. 48-56.

Emeruwa, A. C. (1982) 'Antibacterial substance from Carica Papaya fruit extract', Journal of Natural Products, 45(2), pp. 123-127. doi: 10.1021/np50020a002.

Fakeye, T. O. et al. (2007) 'Effects of Coadministration of Extract of Carica papaya Linn ( family Cariaceae ) on Activity of Two Oral Hypoglycemic Agents', 6(March), pp. 671-678.

Goku, P. E. et al. (2020) 'Comparative Evaluation of the In Vitro Anthelminthic Effects of the Leaves, Stem, and Seeds of Carica papaya (Linn) Using the Pheretima posthuma Model', Evidence-Based Complementary and Alternative Medicine, $2020 . \quad$ doi: 10.1155/2020/9717304.

Hamuel, J. D. (2007) 'Studies on the antibacterial activity of root extracts of Carica papaya L.', African Journal of Microbiology Research, 1(3), pp. 3741.

Juárez-Rojop, I. E. et al. (2012) 'Hypoglycemic effect of Carica papaya leaves in streptozotocin-induced diabetic rats', BMC Complementary and Alternative Medicine, 12 . doi: 10.1186/1472-6882-12-236.

Juárez-Rojop, I. E. et al. (2014) 'Phytochemical screening and hypoglycemic activity of carica papaya leaf in streptozotocin-induced diabetic rats', Brazilian Journal of Pharmacognosy. Sociedade Brasileira de Farmacognosia, 24(3), pp. 341-347. doi: 10.1016/j.bjp.2014.07.012.

Karunamoorthi, K., Kim, H. M., et al. (2014) 'Papaya: A gifted nutraceutical plant', TANG Humanitas Traditional Medicine, 4(1), pp. 1-17. doi: 10.5667/tang.201.

Karunamoorthi, K., Kim, H.-M., et al. (2014) 'Papaya: A gifted nutraceutical plant - a critical review of recent human health research', Tang [Humanitas Medicine], 4(1), pp. 2.1-2.17. doi: 10.5667/tang.2013.0028.

Kovendan, K. et al. (2012) 'Antimalarial activity of Carica papaya (Family: Caricaceae) leaf extract against Plasmodium falciparum', Asian Pacific Journal of Tropical Disease, 2(SUPPL.1). doi: 10.1016/S22221808(12)60171-6.

Krishna, K. L., Paridhavi, M. and Patel, J. A. (2008) 'Review on nutritional, medicinal and pharmacological properties of papaya (Carica papaya linn.)', Indian Journal of Natural Products and Resources, 7(4), pp. 364373.

Lohiya, N. K. et al. (1994) 'Antifertility effects of aqueous extract of Carica papaya seeds in male rats', Planta Medica, 60(5), pp. 400-404. doi: 10.1055/s-2006-959518.

Maheswari, U. et al. (2016) 'FLAVONOIDS: THERAPEUTIC POTENTIAL OF NATURAL PHARMACOLOGICAL AGENTS Invitro anti oxidant activity View project Antibiotics View project 
FLAVONOIDS: THERAPEUTIC POTENTIAL OF NATURAL PHARMACOLOGICAL AGENTS', International Journal of Pharmaceutical Sciences and Research, 7(10), p. $3924 . \quad$ doi: 10.13040/IJPSR.0975-8232.7(10).392430.

Maniyar, Y. and Bhixavatimath, P. (2012) 'Antihyperglycemic and hypolipidemic activities of aqueous extract of Carica papaya Linn. leaves in alloxan-induced diabetic rats', Journal of Ayurveda and Integrative Medicine, 3(2), pp. 70-74. doi: 10.4103/09759476.96519 .

Ngumah, C. (2012) 'Antifungal potencies of leaf extracts of Carica papaya on fungi implicated in soft rot of yam', Ann. Food Sci. Technol., 13(2), pp. 202-209.

Nicolle, E. et al. (2011) 'Flavonoids as Promising Lead Compounds in Type 2 Diabetes Mellitus: Molecules of Interest and Structure-Activity Relationship', Current Medicinal Chemistry, 18(17), pp. 2661-2672. doi: $10.2174 / 092986711795933777$.

Nwofia, G. E., Ojimelukwe, P. and Eji, C. (2012) 'Chemical composition of leaves, fruit pulp and seeds in some Carica papaya ( L ) morphotypes', Int. J. Med. Arom. Plants, 2(1), pp. 200206.

Oboh, G. et al. (2014) 'Inhibition of key enzymes linked to type 2 diabetes and sodium nitroprusside-induced lipid peroxidation in rat pancreas by waterextractable phytochemicals from unripe pawpaw fruit (carica papaya)', Journal of Basic and Clinical Physiology and Pharmacology, 25(1), pp. 21-34. doi: 10.1515/jbcpp-2013-0002.

Omar, H. A. et al. (2016) 'Miean, K. H., \& Mohamed, S. (2001). Flavonoid (myricetin, quercetin, kaempferol, luteolin, and apigenin) content of edible tropical plants.', Journal of agricultural and food chemistry, 49(6), 3106-3112., 18(4), pp. 2315-2344. doi: 10.1109/COMST.2016.2554098.

Owoyele, B. V. et al. (2008) 'Antiinflammatory activities of ethanolic extract of Carica papaya leaves', Inflammopharmacology, 16(4), pp. 168-173. doi: 10.1007/s10787-0087008-0.

Owoyele, B. V, Gbago, A. F. and Ashaolu, O. S. (2013) 'Gastroprotective effects of aqueous extraxt of unripe Carica papaya frui in rats', Pacific Journal of Medical Sciences, 11(2), pp. 2-11.

Rashed, K. et al. (2013) 'Phytochemical Screening of the Polar Extracts of Carica papaya Linn . and the Evaluation of their anti-', Journal of Applied and Industrial Sciences, 1(3), pp. 49-53.

Rashed, K. . and Fouche, G. (2013) 'Anticancer Activity of Carica papaya Extracts in vito and Phytochemical Analysis', Greener Journal of Pharmacy and Pharmacology, 1(1), pp. 1-5.

Ravikant, T. et al. (2012) 'Root bark ( caricaceae ) in Renal Artery Occluded Hypertensive Rats .', 4(3), pp. 20-23. 
Saidu, A.N and Nweri c, G. (2013) 'Phytochemical Screening and Effects of Methanol Extract of Carica papaya Stem bark in alloxan induced Diabetic Rats', 4(6), pp. 819-822.

Sree Padma Priya S , Jayakumar. K, Vijay Mathai , Chintu. S, S. B. . (2012) 'International Journal of Medical and Health Sciences', Ijmhs.Net, (July), pp. $10-16$. doi: 10.18488/journal.9/2015.2.2/9.2.36.49.

Srikanth, G. et al. (2010) Studies on invitro antioxidant activities of carica papaya aqueous leaf extract, Research Journal of Pharmaceutical, Biological and Chemical Sciences.
Tarun, V. (2015) 'review on medicinal properties of C arica papaya L inn .', Asian Pacific Journal of Tropical Disease, 5(July), pp. 1-6. doi: 10.1016/S2222-1808(14)60617-4.

Tolunigba Abisola, O. and Adekunle Wahab, O. (2012) 'Gastro-protective activity of aqueous Carica papaya seed extract on ethanol induced gastric ulcer in male rats', African Journal of Biotechnology, 11(34), pp. 8612-8615. doi: 10.5897/AJB12.034.

Yogiraj, V. et al. (2014) 'Carica papaya Linn: an overview.', International Journal of Herbal Medicine, 2(5 Part A), pp. 1-8. 